\title{
A Cause Without Rebels? Om emancipationens forsvundne subjekt
}

af ANDREAS BECK HOLM

SLAGMARK \#7I

SIDER: $29-43$

Arbejderbevægelsen indtager en særstilling i de sociale bevægelsers historie. Den er ikke blot en af de første bevægelser, den er også og uden sammenligning den mest succesrige. Og endelig har den i sin kamp for det klasseløse samfund været den mest radikale.

Udgangspunktet for det følgende er imidlertid den antagelse, at bevægelsens historiske politiske radikalitet ikke fandt teoretisk udtryk i lige så radikale termer, men derimod blev formuleret i inadækvate begreber overtaget fra den filosofiske tradition. Af særlig betydning er her begrebet 'subjekt', der genfindes i forestillingen om arbejderne som 'emancipationens (eller revolutionens) subjekt'. Helt konkret skal fire teser derfor søges underbygget. For det første at denne forestilling er ideologisk. For det andet at arbejderklassen som politisk subjekt ved sit fravær producerer specifikke symptomer først i Karl Marx' tekster og siden i den marxistiske tradition. For det tredje at de opgør med forestillingen om arbejderklassen som politisk subjekt, man finder hos dels Ernesto Laclau og Chantal Mouffe, dels Michael Hardt og Antonio Negri, 
ikke er tilstrækkeligt radikale, og endelig, for det fjerde, at en konsekvent nytænkning af ikke blot det politiske aktørbegreb, men også arbejderklassens rolle og begrebet 'revolution' med fordel kan baseres på Louis Althussers strukturelle samfundsforståelse.

Endelig kan én mere overordnet tese siges at fungere som rettesnor for de følgende analyser, nemlig at den ovennævnte nytænkning kan styrke venstrefløjens politiske praksis specifikt og de praksisser, der kendetegner de sociale bevægelser generelt.

\section{A CITY OF TWO TALES}

I 1845 bryder Marx med sin ungdoms feuerbachske problemstilling. Dette brud er formidlet af mødet med Friedrich Engels og af sidstnævntes rapport om de arbejdende klasser i England (Marx \& Engels, 1990, s. 225-506). Også i sine ungdomsværker taler Marx ganske vist om 'proletariatet', men begrebet har her ikke rod i en viden om de faktiske arbejdere; dets funktion er snarere at indløse den unge Marx' filosofikritik. Som det hedder i Kritik af den hegelske retsfilosofi: "Tyskerens frigørelse er menneskets frigørelse. Denne frigørelses hjerne er filosofien, dens hjerte er proletariatet. Filosofien kan ikke virkeliggøre sig selv uden at proletariatet ophæves, proletariatet kan ikke ophæve sig selv uden at filosofien virkeliggøres" (Marx, 1968, s. 66). Efter læsningen af Engels' rapport ændrer begrebet karakter. Nu er proletariatet de faktiske arbejdere i Manchester, og 'frigørelsen' bliver deres klassekamp. For Marx bliver det nu afgørende, at arbejderklassen er en politisk aktør, at den selv må befri sig fra sine lænker. Det er en af de ting, der ifølge Marx selv adskiller ham fra de andre socialistiske teoretikere i samtiden (Marx, 1933, s. 100). Og det definerer en klar politisk opgave, nemlig klassens bevidstgørelse om sin historiske rolle. Denne opgave får ham til at skelne mellem proletariatet i og for sig selv - altså som henholdsvis offer for udbytning og politisk aktør. Begrebet 'emancipatorisk subjekt' er en meget præcis sammenfatning af denne tankegang, idet ovennævnte distinktion baserer sig på en kontrastering af subjekt og objekt: Mens arbejderne i dag er objektet for udbytning, skal de blive subjekter for deres egen befrielse. Med Marx' egne ord: 
De $\varnothing$ konomiske forhold har først forvandlet befolkningens masser til arbejdere. Kapitalens herredømme har skabt en fælles situation, fælles interesser hos denne masse. Således er denne masse allerede en klasse over for kapitalen, men endnu ikke for sig selv. I den kamp, som vi kun har opridset i nogle af dens faser, finder denne masse sammen, konstituerer sig som klasse for sig selv. De interesser, som den forsvarer, bliver klasseinteresser. Men kampen klasse mod klasse er en politisk kamp. (Marx, 1973, s. 120)

Manifestet fra 1848 skal netop bevidstgøre arbejderne om deres fælles interesser, altså transformere dem til politisk aktør. Dets opråb til proletariatet om at forene sig ligger altså i klar forlængelse af Marx’ ræsonnement i citatet ovenfor.

Samtidig udløser Februarrevolutionen i Paris næsten fire års tumultarisk politisk udvikling, som Marx analyserer i Klassekampene i Frankrig 18481850 og Louis Bonapartes 18. Brumaire (Marx, 1933, 1947). Ganske vist påpeger han (Marx, 1933, s. 30-32), at arbejderklassen kun i en alliance med andre klasser kan omstyrte det siddende regime, men med gennemtvingelsen af republikken den 25. februar manifesterer den sig alligevel for første gang som en selvstændig magt (Marx, 1933, s. 31). Revolutionen tømmes dog allerede i juni for emancipatorisk potentiale, idet de parisiske arbejderes nye opstand, Junirevolutionen, bliver slået ned. Paris bliver således for Marx rammen om to forskellige fortællinger: Den smukke Februarrevolution og den hæslige Junirevolution (Marx, 1933, s. 45).

I sit forord til genudgivelsen af Klassekampene i Frankrig i 1895 vedgår Engels åbent, at han og Marx troede, "at den store afgørelseskamp var udbrudt, at den maatte blive udkæmpet i en eneste lang og omskiftende revolutionsperiode, men at den kun kunde ende med proletariatets endelige sejr." (Marx, 1933, s. 10). Han giver imidlertid ikke køb på ideen om, at revolutionen må gennemføres af arbejderklassen; tiden var i 1848 blot ikke 'moden' (Marx, 1933, s. 13), og arbejderne må 'bevidstgøres', før de kan omstyrte kapitalismen (Marx, 1933, s. 20).

De samme synspunkter findes i teksterne selv. Mere bemærkelsesværdig er imidlertid Marx' opfindelse af et nyt klassebegreb: Pjalte- eller 
lumpenproletariatet. Det er borgerskabets mobilisering af dette pjalteproletariat i den såkaldte mobilgarde, der sætter det i stand til at nedkæmpe Junirevolutionen. Dermed tillægges pjalteproletariatet en central rolle i forklaringen af revolutionens nederlag.

Marx' begreb om pjalteproletariatet er kontroversielt. Det er ofte blevet kritiseret (se f.eks. Bussard, 1987 og Cowling, 2002), selv om man også finder teoretikere, der forsvarer brugen af det (f.eks. Thoburn, 2011). Mens hans øvrige klassekategorier, og især de to afgørende, proletariat og bourgeoisi, er rimeligt klart definerede ved deres stilling i samfundets produktion, udgør pjalteproletariatet en anomali, idet det primært defineres stipulativt. I Klassekampene gives følgende karakteristik af

pjalteproletariatet, som i alle storbyer udgør en masse, der er skarpt adskilt fra industriproletariatet, et rekrutteringssted for tyve og forbrydere af enhver art, levende af samfundets affald, folk uden bestemt arbejdsfag, omstrejfere, gens sans feu et sans aveu, af forskellig art alt efter dannelsesgraden af den nation, de tilhører, men aldrig fornægtende lazaronkarakteren [...]. (Marx, 1933, s. 39)

I Louis Bonapartes 18. Brumaire suppleres med nedenstående:

Ved siden af ruinerede Levemænd med tvivlsomme Eksistensmidler og af tvivlsom Oprindelse, ved siden af forhutlede Eventyrere fra Bourgeoisiets Rækker så man Vagabonder, hjemsendte Soldater, frigivne Tugthusfanger, bortrømte Galejslaver, Svindlere, Gøglere, Lazaroner, Lommetyve, Taskenspillere, Falskspillere, Alfonser, Bordelværter, Dragere, Literater, Lirekassemænd, Kludehandlere, Skærslippere, Kedelflikkere, Tiggere, kort sagt hele denne ubestemmelige, opløste omtumlede Masse, Franskmændene betegner som la Boheme. (Marx, 1947, s. 63)

På samme side sammenfatter Marx pjalteproletariatet som "dette Udskud, Bærme, Afskum fra alle Klasser". Andre steder henføres også 
finansaristokratiet til denne kategori (Marx, 1933, s. 28), ligesom Marx udnævner Louis Bonaparte til "Pjalteproletariatets Chef” (Marx, 1947, s. 63). Hvorfra kommer dette begreb? Robert L. Bussard (1987) viser, hvordan det trækker på overklassens frygt og foragt for proletariatet - et begreb, der sammenfattede disse negative konnotationer. Samtidig med at Marx og Engels italesætter proletariatet i positive termer, fører de dets negative betydningsindhold over i det nye begreb om pjalteproletariatet, der således bliver en ny nedsættende betegnelse for de særligt fattige grupper, der med deres manglende klassesolidaritet splitter proletariatet indefra. Det er, som Bussard medgiver, ikke overraskende, at Marx og Engels ikke er immune over for samtidens borgerlige ideologi, der således bag ryggen på dem sniger sig ind i deres begrebsapparat.

Problemet med Bussards udlægning er imidlertid, at han i sin kritik tillægger pjalteproletariatet mere begrebslig konsistens, end der er grundlag for. For betegnelsen angiver jo netop ikke bare samfundets allerfattigste, men som sagt også finansaristokratiet, børsspekulanter og endda republikkens præsident. Dertil kommer, at Marx opererer med en særlig underkategori, nemlig "Bondepjalteproletariatet", som (heller) ikke forklares nærmere (Marx, 1947, s. 111). Og endelig er Marx' ovenfor citerede påstand om, at pjalteproletariatet er 'skarpt adskilt fra industriproletariatet' åbenlyst forkert. Selv den bedste industriproletar kan i krisetider blive gjort til tigger, til lirekassemand osv.; tværtimod at være 'skarpt adskilte' kategorier er pjalteproletaren = industriproletaren + økonomisk krise.

Mens det forekommer plausibelt med Bussard at hævde, at begrebet får sin retoriske kraft fra overklassens frygt for 'de farlige klasser', kan det derfor ikke selv betegne en klasse i økonomisk forstand. Det angiver heller ikke en klasse i politisk forstand; pjalteproletarerne har ifølge Marx ingen selvstændige klasseinteresser, men kan mobiliseres for enhver sag (Marx, 1933, s. 39). Som det fremgår af citaterne ovenfor, er kategorien hverken politisk eller økonomisk, men moralsk. Pjalteproletariatet er "afskum" fra alle og dermed ingen klasser. Og som en moralsk fordømmelse udgør begrebet et fremmedlegeme i Marx' teoridannelse. Pjalteproletariatet er et symptom. Men på hvad?

Man kan skelne mellem to niveauer i Marx' forståelse af nederlaget i 1848 . For det første hvad vi kan kalde det marxistiske niveau, altså et niveau af 
forklaringer, som vi ud fra marxistisk teori i øvrigt vil forvente: De økonomiske konjunkturer ændredes, og borgerskabet stod politisk og militært stærkere end proletariatet. Og så er der, for det andet, hvad vi kan kalde et ideologisk niveau, niveauet for kategorien pjalteproletariat. Når Marx supplerer sin teoretisk velfunderede analyse med denne fabel om en ikke-klasse, der saboterer den sociale revolution for arbejderne, kan det udlægges som en insisteren på, at arbejderklassen må være, hvad den marxistiske analyse netop viser, at den i 1848 ikke er, nemlig en samlet, handlekraftig politisk aktør, et subjekt. At revolutionen mislykkes forklares på dette niveau med moralsk anløbne individer, der er 'skarpt adskilte' fra proletariatet. Denne 'skarpe adskillelse' er med andre ord den begrebslige kerne i pjalteproletariatet. Når det giver mening her at tale om to forskellige niveauer, er det altså fordi de to forklaringer er gensidigt udelukkende, de forudsætter en henholdsvis strukturel marxistisk og en humanistisk essentialistisk logik.

Hvorfor er det andet forklaringsniveau ideologisk? Fordi det viser tilbage til logikken i Marx' ungdomsskrifter, hvor et samlet proletariat som sagt var en begrebslig nødvendighed; og det viser endnu længere tilbage, nemlig til G.W.F. Hegel og forestillingen om, at historien har et subjekt - en forestilling, hvis ideologiske karakter Althusser har demonstreret (Althusser, 1996b, s. 161224). 'Pjalteproletariatet' er altså et symptom på, at Marx i 1852 endnu ikke helt har frigjort sig fra sine tidligere ideologiske forestillinger. Det skyldes bl.a. grundlæggende svagheder i Engels' rapport om arbejderklassen i England. Bruce Mazlish påpeger, at Engels ud fra sine observationer af forholdene i Manchester foretager forhastede generaliseringer om arbejderklassen i det hele taget, eksempelvis at den skulle være immun over for religiøs indoktrinering (Mazlish, 1990, s. 741).

Problemet med ideologiske synspunkter er ikke, at de er forkerte, men at de er politisk kontraproduktive. Således også med ideen om det politiske subjekt, der står i vejen for analysen af faktiske politiske udviklinger og i modsætning til venstrefløjens praktiske erfaringer. Her er Marx' bortforklaring af Junirevolutionens nederlag med pjalteproletariatet det første, men ikke eneste eksempel. Slavoj Žižek viser således, hvordan begrebet 'subkulak' i Sovjetunionen kommer til at spille den samme rolle som 'pjalteproletariatet' i Marx’ retorik (Žižek, 2012, s. 203-205). I praktisk politik har vi for øvrigt i 
Danmark i de senere år i 'arbejderisternes' insisteren på, at arbejderpolitik ikke handler om at styrke dem, der står uden for arbejdsmarkedet, men om at gavne "Hårdtarbejdende lønmodtagere. Dem der står tidligt op, smører leverpostejsmadder, afleverer ungerne og tager på arbejde" (Pedersen, 2012), en gentagelse af den ideologi, der sætter en 'skarp adskillelse' op mellem pjalteproletariat og arbejderklasse.

Flere forestillinger i den marxistiske tradition er knyttet til princippet om arbejderklassen som politisk subjekt. Eksempelvis at klassen skal være tilstrækkeligt 'moden' for at kunne gennemføre sin egen revolution. I praksis har denne forestilling udfyldt mindst én af følgende funktioner: Bortforklaring af revolutionære nederlag ('tiden var ikke moden'), styrkelse af statsapparatet (med det formål at fremskynde industrialisering og dermed arbejdernes 'modning'), eksempelvis i Sovjetunionen, og magtens centralisering i partiet (fordi klassen som helhed ikke var 'moden' til demokrati), sådan som den er typisk for leninismen. Fællesnævneren for disse funktioner er, at de har været direkte politisk kontraproduktive, enten ved at hæmme forståelsen af den politiske udvikling eller ved at trække den i en retning, der i historisk tilbageblik synes problematisk. Endnu en kontraproduktiv forestilling er distinktionen mellem borgerlige og proletariske revolutioner, som Marx gør meget ud af i Louis Bonapartes 18. Brumaire. Den slører, at revolutioner ikke som sådan er hverken borgerlige eller proletariske, men kan lede i forskellige retninger.

Et mere grundlæggende problem er den implicitte logik i kontrasteringen af objekt og subjekt, altså klassen 'i' og 'for sig'. Subjektet er aktivt, det handler på det passive objekt. Og det er en enhed (ellers er der ikke ét, men flere subjekter). Når traditionen ser arbejderklassen som subjekt for social forandring, kommer denne logik til udtryk i opfattelsen af arbejderne som en homogen gruppe, der aktivt intervenerer i samfundet forstået som et objekt, der ligger uden for det. Arbejderklassen er imidlertid ikke en politisk enhed, den er ikke adskilt fra (og dermed immun over for ideologisk påvirkning fra) samfundet, og den er lige så 'passiv' som 'aktiv' i sin interaktion med det. Det ved marxistiske teoretikere og praktikere naturligvis godt. Påstanden er imidlertid, at deres indsigter modarbejdes af subjektbegrebets logik. Når Althusser (Althusser \& Poulantzas, 1972) derfor karakteriserer subjektkategorien som indbegrebet af 
ideologi, er det en erkendelse, der gælder ikke blot individuelle aktører, men også samfundsklasser.

Man kan argumentere for, at Marx med tiden frigør sig fra den ideologiske tankegang. Et første symptom er, at 'pjalteproletariatet' gradvist holder op med at spille en vigtig teoretisk rolle i hans tekster. Sammenligningen med hans analyse af borgerkrigen i 1871 er i den sammenhæng slående: Her optræder pjalteproletariatet netop ikke i karakteristikken af Kommunens modstandere (Marx, 1974, s. 64-66). Denne udvikling finder sted samtidig med, at økonomikritikken efter 1852 kommer til at fylde stadig mere i hans forfatterskab. Og det er præcis, hvad man måtte forvente: Med styrkelsen af Marx' strukturelle økonomiske forståelse bliver pjalteproletariatet som politisk forklaringskategori overflødig. Man kunne fremføre den hypotese, at inkonsistensen i Marx' forklaringer af Februarrevolutionen medvirker til at intensivere hans økonomikritiske studier.

I eksempelvis Kapitalen (Marx, 1970-72) er proletariatet som politisk subjekt fraværende, mens værket til gengæld afdækker den relation mellem arbejde og kapital, der definerer arbejdernes økonomiske grundvilkår. Marx’ optimisme i forhold til arbejderklassen som politisk subjekt synes desuden at kølnes (Mazlish, 1990, s. 746-747). Han sætter ikke noget nyt 'subjekt' i dets sted, måske fordi han fortsat mener, at revolutionen skal komme fra arbejderklassen. Den udlægning understøttes af, at han endnu i Borgerkrigen i Frankrig taler om arbejderklassen i "fuld bevidsthed om sin historiske mission" (Marx, 1974, s. 58). Man kan imidlertid også hæfte sig ved konteksten for dette og lignende udsagn: Det er i Marx' mest direkte politiske skrifter, arbejderklassen endnu præsenteres som politisk subjekt. Måske forstod Marx den politiske nødvendighed af fortsat at italesætte arbejderne som politisk subjekt, fordi det var blandt dem, Socialdemokratiet primært hentede støtte. Teoretisk var han imidlertid nået til forståelse af, at revolutionære samfundsforandringer ikke har noget 'subjekt'.

Under alle omstændigheder levede princippet om arbejderklassens 'historiske mission' videre i den marxistiske tradition. Her skal blot nævnes et enkelt eksempel. 


\section{LUKÁCS OG PARTIET}

I György Lukács' Historie og Klassebevidsthed er proletariatet historiens subjekt, men for at kunne spille denne rolle er det nødt til at blive sig sin opgave bevidst (Lukács, 1990, s. 37-45). Dets klassebevidsthed er altså et politisk og historisk mål, ikke et psykologisk faktum. Den defineres af Lukács som "de rette og rationelle reaktioner" på "en særlig position i produktionsprocessen." (Lukács, 1990, s. 51). Arbejderklassen defineres altså som politisk subjekt i det omfang, den handler i overensstemmelse med sine økonomiske klasseinteresser.

Så længe arbejdernes klassebevidsthed er 'umoden' (Lukács, 1990, s. 304-306) har de brug for partiet. Det er for Lukács den proletariske klassebevidstheds konkrete form (Lukács, 1990, s. 42). Og som sådan er det en fuldkommen homogen organisation, der agerer som proletariatets repræsentant, beskytter og avantgarde.

Hvad Lukács derfor ønsker at sige er, at ikke-sammenfaldet mellem proletariatets livsbetingelser og klassebevidsthed er uvæsentligt, eftersom dets ophævelse er garanteret af og ved historiens afslutning. Hvad han faktisk siger, er at ikke-sammenfaldet er en realitet: Arbejderne udgør ikke nogen politisk enhed.

Dette ikke-sammenfald strukturerer hele Historie og Klassebevidsthed. Det nødvendiggør Lukács' historisk-teleologiske perspektiv på proletariatet, og det dikterer forståelsen af klassebevidstheden som noget andet end de faktiske arbejderes bevidsthed, men også som sidstnævntes naturlige endemål. Endelig forklarer ikke-sammenfaldet kommunistpartiets centrale betydning. Det er karakteristisk, at Lukács intet har at sige om, hvilken konkret politik, der kvalificerer partiet til at udfylde rollen som den praktiske inkarnation af proletarisk klassebevidsthed. Fra hans synspunkt er dette spørgsmål misforstået: Partiet udfylder sin rolle per definition. Var det ikke tilfældet, ville der nemlig ikke længere være noget, i forhold til hvilket den proletariske bevidsthed kunne karakteriseres som umoden, og heller ingen garanti for dens fremtidige modenhed. Uden et idealiseret parti ville han være nødt til at indrømme, at proletariatet er politisk fragmenteret. 
'Partiet' har altså kun én funktion, nemlig at være den perfekte politiske enhed, som arbejderklassen ikke er. Det er derfor, Lukács insisterer på, at det er fuldstændig homogent. 'Partiet' spiller med andre ord hos Lukács den samme rolle som 'pjalteproletariatet' hos Marx, nemlig at usynliggøre, at arbejderklassen som politisk subjekt ikke eksisterer.

\section{POST- OG NEOMARXISTISKE ALTERNATIVER}

Med marxismens krise i 1970'erne forsvinder også troen på arbejderklassen som revolutionens subjekt. Laclau og Mouffe er blandt de første, der drager konsekvensen heraf. Ifølge dem er det "nødvendigt at [...] forkaste ideen om en perfekt forenet og homogen aktør, såsom 'arbejderklassen' i den klassiske diskurs." (Laclau \& Mouffe, 2001, s. 84). Heri ligger deres opgør med 'klassereduktionismen' i den marxistiske politikforstålse (Laclau \& Mouffe, 2001, s. 65-71). I stedet må man se politiske subjekter som konstruerede i det politiske spil selv, gennem italesættelsen af kollektive identiteter. Postmarxistisk venstrefløjspolitik handler altså her ikke om at forsvare interesser, der ligger før og uden for det politiske (klasseinteresser), men om gennem artikulationen af forskellige elementer at konstruere en praksisbaseret hegemonisk subjektivitet.

Hardt og Negri afviser ganske vist den klassiske idé om revolution som forældet (Hardt \& Negri, 2005, s. 89) sammen med den arbejderklasse, der ikke er forsvundet, men territorialt forskudt og ikke længere hegemonisk (Hardt \& Negri, 2003, s. 247). 'Multituden' er imidlertid i deres fremstilling arbejderklassens direkte arvtager (Hardt \& Negri, 2003, s. 161). Den udgøres af alle dem, der udbyttes af kapitalen, men til forskel fra arbejderklassen skal den forstås som et netværk snarere end en enhed. Hardt og Negri bruger metaforer som 'bisværm' til at vise, hvordan 'Multituden' trods de store forskelligheder, der kendetegner den, kan handle som en samlet kraft og konfrontere en magt, der som 'Imperie' også er blevet netværksbaseret (Hardt \& Negri, 2005, s. 5462). 'Multitudens' diversitet forhindrer den altså ikke i at have fælles interesser, og den forhindrer heller ikke forfatterne i at fremhæve nødvendigheden af dens politiske organisering (Hardt \& Negri, 2003, s. 384). 
Forskellighederne mellem de to tilgange er markante. Laclau og Mouffe kapper som sagt forbindelsen til arbejderklassen som privilegeret grundlag for politisk praksis, og opgiver i den forbindelse også tanken om revolutionær samfundsforandring. Hardt og Negri afviser ganske vist traditionelle forestillinger om revolution (hvilket i sig selv er uhyre traditionelt, det gør også allerede Engels (Marx, 1933, s. 19-20)), men sætter alligevel 'Multituden' op som decideret modmagt til 'Imperiet' og understreger dens materielle forankring i udbytningen.

Er disse alternativer imidlertid radikale nok i deres brud med traditionens forestilling om arbejderklassen som emancipatorisk subjekt? Bliver der ikke en rest af subjektbegrebets logik tilbage? Laclau og Mouffe understreger, at politiske subjektiviteter er porøse og midlertidige konstruktioner, men hævder alligevel at politik består i skabelsen af sådanne subjektiviteter (Laclau \& Mouffe, 2001, s. xvii) med henblik på etableringen af et hegemoni, et herredømme. Heller ikke Hardt og Negri ser noget problem i at karakterisere 'Multituden' som en politisk subjektivitet (Hardt \& Negri, 2005, s. 198), og for dem er målet at 'Multituden', trods sin diversitet, bliver i stand til at handle som en enhed. I begge tilfælde er 'subjektiviteten' netop forstået som subjekt: Den er aktiv, samlet og har initiativet. Man kan derfor hævde, at kritikken og/eller fornyelsen af marxismen i begge tilfælde består i en afvisning af arbejderklassen og/eller forestillingen om revolution, og man kan argumentere for, at kritikerne dermed forveksler den nødvendige kritik af traditionens logik med de begreber (arbejderklasse, parti, revolution...), som traditionen har tænkt i denne logik.

\section{REVOLUTIONENS TEATER}

Der er grund til at være skeptisk over for at afskrive arbejderne som politisk faktor i en tid, hvor lønarbejdet er blevet universaliseret, udbytningen skærpet (Boltanski \& Chiapello, 2007), og den tredje verden industrialiseret. Der er også grund til at være skeptisk over for afvisningen af revolutionære omvæltninger som noget fortidigt; fra Iran til Egypten er de seneste 35 års historie i høj grad blevet formet af revolutioner. Til gengæld er det ovenfor søgt demonstreret, at subjekttænkningen er ideologisk og dermed politisk 
kontraproduktiv, hvorfor der er grund til at forsøge at formulere det politiske aktørbegreb samt begreberne revolution og arbejderklasse uafhængigt af denne tænknings logik. Nedenfor skal det blot antydes, hvilken retning en sådan nytænkning kan tage.

Vi besidder allerede det teoretiske grundlag for et mere konsekvent opgør med subjektkategorien, tilmed et teoretisk grundlag, der systematiserer og udvikler det, der ovenfor blev kaldt det marxistiske forklaringsniveau i Marx' undersøgelser af Februarrevolutionen. I Althussers rekonstruktion af Marx' problemstilling forstås samfundet som en klynge af relativt autonome niveauer, eksempelvis økonomi, politik og ideologi (Althusser, 1996 s. 281). At de er relativt autonome betyder, at deres udvikling hver især afspejler de modsætninger, der karakteriserer det specifikke niveau. At de kun er relativt autonome angiver til gengæld, at de forskellige niveauer overdeterminerer hinanden, og at de dermed er overdeterminerede af samfundet som helhed. Af samme grund kan Althusser med et par berømte formuleringer karakterisere samfundet som en struktur uden et centrum og historien som et teater uden forfatter (Althusser, 1996, s. 338, 411). Samtidig afviser han som sagt kategorien subjekt som ideologisk, idet samfundets ideologiske statsapparater netop har til formål at 'interpellere' individerne til subjekter (Althusser og Poulantzas, 1972). Den sociale formation er altså ikke skabt af et 'subjekt' den skaber tværtimod subjekter.

Også revolutionære omvæltninger kan ses som processer uden et subjekt, som overdeterminerede sammenbrud i specifikke historiske samfundsstrukturer. Talrige politiske aktører gør sig gældende i sådanne omvæltninger, men ikke ét subjekt. Når revolutionen er en kendsgerning, står kampen netop om, hvilken 'subjektivitet', hvilken dagsorden, den (ideologisk) skal ses som udtryk for. At det er revolutionen, der udløser kampen om dens subjektivitet forklarer, hvorfor intet 'subjekt' nogensinde er 'modent' til at gennemføre en samfundsomvæltning. I 1789 var det eksempelvis ikke 'det franske folk', der gennemførte revolutionen; det blev skabt i den. Når Februarrevolutionen er en farce, hvis aktører klæder sig i fortidens gevandter, er det altså ikke fordi, som Marx siger, at 'frasen' i den borgerlige revolution "førte ud over indholdet" (Marx, 1947, s. 16). Det er fordi, de borgerlige revolutionære er ude af stand til at give nyt indhold til en omvæltning, de dybest set ikke ønsker og mod deres 
egen vilje pludselig står som aktører i. På den ene side dækker deres referencer til eksempelvis 1789 altså over deres modsætning, reaktionen. På den anden side er der fuld overensstemmelse mellem sag og frase, for sagen er her flugten fra fremtiden.

En politisk aktør, der ikke er subjekt, skaber aldrig revolutioner, bliver aldrig hegemonisk, er aldrig en enhed, men er altid henvist til at reagere på samfundsudviklinger, der i kraft af deres overdeterminerede natur ikke kan forudsiges, og som påvirker aktørens egen udvikling. En arbejderklasse, der aldrig er forenet, får ikke sin politiske betydning derved, at den har sit eget parti og kan optræde samlet. Men venstrefløjspartier som politiske aktører er karakteriseret ved at styrke muligheden for revolution gennem deres bekæmpelse af arbejdets udbytning. Derfor er det altid oplagt også at søge støtte blandt lønarbejderne. Til gengæld bortfalder det klassiske pseudoproblem, at arbejderpartierne aldrig har samlet hele arbejderklassen, men til gengæld altid også tiltrukket individer fra andre klasser. Det er netop kun et problem, hvis man ser arbejderklassen selv som politisk aktør og partiet som dens 'repræsentant'.

Påstanden er i det hele taget, at teorien med opgivelsen af forestillingen om et emancipatorisk subjekt intet taber, men derimod bliver mere stringent og $\mathrm{i}$ bedre overensstemmelse med venstrefløjens historiske erfaringer.

\section{MANY REBELS, NO SUBJECT}

Moderne (idé)historie er i høj grad blevet formet af sociale bevægelser; ingen af dem har imidlertid udfyldt rollen som 'subjekt'. Og derfor forstår man hverken disse bevægelser eller deres betydning, hvis man italesætter dem inden for rammerne af subjektbegrebets forældede og ideologiske logik. Det er en pointe med generel gyldighed. Men dens betydning er aldrig så tydelig som i arbejderbevægelsen. I det foregående er det således blevet søgt demonstreret, hvordan subjekttænkningen her historisk har haft meget konkrete uheldige politiske og organisatoriske virkninger.

Arbejderklassen har aldrig været politisk aktør, og politiske aktører er aldrig 'subjekter'. Hvor andre teoretikere (f.eks. Filc og Ram, 2014) derfor stadig diskuterer alternativer til arbejderklassen som historisk emancipatorisk 
subjekt, er der her blevet argumenteret for at opgive forestillingen om et sådant subjekt. Påstanden har været, at den ikke blot er politisk problematisk, men også, i et teoretisk perspektiv, ideologisk. Og at den derfor står i modsætning til de historiske erfaringer og forhindrer venstrefløjen i at drage fuldt udbytte af disse. Påstanden har imidlertid også været, at denne forestilling kan opgives, uden at man sætter hverken principper eller indsigter over styr. I det foregående er det således med henvisning til Althusser blevet antydet, hvordan venstrefløjspartier kan forstås som politisk aktører, der ikke er subjekter. Andre sociale bevægelser kan med fordel forstås i samme perspektiv.

Marx forivrede sig, da han for at markere en kontrast til andre socialistiske teoretikere udnævnte arbejderklassen til politisk subjekt. Skønt kontrasten var reel, lå den nemlig ikke i dette 'subjekt', men i den økonomikritik, som han endnu på dette tidspunkt kun havde antydet rammerne for. Derfor kan man hævde, at ovenstående er en korrektion ikke blot af, men med Marx. Det er hans strukturelle analyse, sådan som den videreudvikles af Althusser, der muliggør en forståelse af både politiske aktører, revolutionære udviklinger og arbejderklassens politiske betydning - en forståelse, der adskiller sig væsentligt fra den misforståelse, forestillingen om et emancipatorisk subjekt rummer.

LITTERATUR

Althusser, L. \& Poulantzas, N. (1972). Om ideologiske statsapparater / Om marxisme og retten. Aarhus: Ukendt forlag.

Althusser, L. (red.). (1996). Lire le Capital. Paris: PUF.

Althusser, L. (1996b). Pour Marx. Paris: La Découverte.

Boltanski, L. \& Chiapello, E. (2007). The New Spirit of Capitalism. London: Verso.

Bussard, R. L. (1987). The 'Dangerous Class' of Marx and Engels: The Rise of the Idea of the Lumpenproletariat. History of European Ideas, 8(6), 675-692. doi:10.1016/01916599(87)90164-1

Cowling, M. (2002). Marx's Lumpenproletariat and Murray's Underclass: Concepts Best Abandoned?. I M. Cowling \& J. Martin (red.), Marx's 'Eighteenth Brumaire': (Post) modern Interpretations (s. 228-242). London: Pluto Press.

Filc, D. \& Ram, U. (2014). Marxism after postmodernism: Rethinking the emancipatory political subject. Current Sociology, 62(3), 295-313. doi: 10.1177/0011392114525794

Hardt, M. \& Negri, A. (2003). Imperiet. København: Informations Forlag. 
Hardt, M. \& Negri, A. (2005). Multitude: War and Democracy in the Age of Empire. London: Penguin Books.

Laclau, E. \& Mouffe, C. (2001). Hegemony and Socialist Strategy. London: Verso.

Lukács, G. (1990). History and Class Consciousness. London: Merlin Press.

Marx, K. (1933). Klassekampene i Frankrig 1848-50. København: Mondes Forlag.

Marx, K. (1947). Louis Bonapartes 18. Brumaire. København: Forlaget Fremad.

Marx, K. (1968). Økonomi og Filosofi. København: Gyldendal.

Marx, K. (1970-72). Kapitalen. København: Rhodos.

Marx, K. (1973). Filosofiens Elendighed. Viborg: Jørgen Paludans Forlag.

Marx, K. (1974). Pariserkommunen (Borgerkrigen i Frankrig). København: Forlaget Tiden.

Marx, K. \& Engels, F. (1990). Werke: Bd. 2. Berlin: Dietz Verlag.

Mazlish, B. (1990). Marx's Historical Understanding of the Proletariat and Class in 19th -Century England. History of European Ideas, 12(6), 731-747. doi: 10.1016/01916599(90)90207-U

Pedersen, T. M. (2012, 17. januar). En skattereform til dem der trækker læsset. Berlingske Tidende. Hentet fra http://www.b.dk/kommentarer/en-skattereform-til-dem-dertraekker-laesset

Thoburn, N. (2002). Difference in Marx: the lumpenproletariat and the proletarian unnamable. Economy and Society, 31(3), 434-460. doi: 10.1080/0308514022015188

Žižek, S. (2012). Living in the End Times. London: Verso. 
